\title{
THE DEVELOPMENT OF A WEB-BASED LEARNING TO IMPROVE A CREATIVE WRITING ABILITY
}

\section{Atikah Mumpuni, Laelia Nurpratiwiningsih}

Universitas Muhadi Setiabudi

atikahmumpuni@gmail.com

\section{Article History}

accepted 09/07/2018

approved 01/08/2018

published 17/09/2018

\section{Keywords}

Development Web, Creative Writing

\begin{abstract}
Writing was considered as difficult by most of students due tue lack of a practice in materializing ideas into a writing language. Therefore, it was needed a writing learning that provides a medium for students to train materializing that ideas. This research was aimed to develop a web-based learning in form of learning devices that comprise of 1) syllabus; 2) Class Event Unit (SAP); web-based learning media dan 4) instrument of a feasible and effective creative writing assessment in improving a student writing ability. This was a Research and Development (R\&D) study method developed by Borg and Gall. There were two results include: 1) product feasibility viewed from material expert assessment and student response that jointly assess good. 2) product effectiveness based on average improvement and difference of writing ability, a treatment-given group obtain a better result. A web-based learning developed was declared feasible and effective in improving a student creative writing ability.
\end{abstract}

Social, Humanities, and Education Studies (SHEs): Conference Series https://jurnal.uns.ac.id/shes 


\section{PENDAHULUAN}

Teknologi informasi dan komunikasi yang serba canggih, perlu diimbangi dengan pembelajaran yang mengimplementasikan teknologi tersebut. Hal ini dilakukan agar peserta didik siap menghadapi kemajuan teknologi informasi dan menggunakannya dengan bijak dalam kehidupan. Salah satu pembelajaran yang dapat diterapkan yaitu pembelajaran berbasis web. Web merupakan sebuah halaman yang diakses menggunakan internet dan memuat informasi berupa tulisan, gambar, suara, video, atau perpaduan keempatnya.

Mahasiswa umumnya telah terampil memanfaatkan halaman web untuk mencari informasi, terutama dalam menyelesaikan tugas perkuliahan. Hal tersebut dapat dilihat dari tugas-tugas yang dibuat, khususnya makalah kebanyakan bersumber dari alamat web tertentu. Tugas yang hanya bersumber pada informasi dalam halaman webberdampak kurang baik, seperti meningkatnya plagiasi serta memudarnya kreativitas dan kekritisan mahasiswa. Oleh sebab itu, diperlukan pembelajaran yang juga melibatkan mahasiswa pengolahan web tersebut.

Pengelolaan web dalam proses pembelajaran dilakukan dengan memanfaatkan domain gratis, seperti blogspot dan wordpress. Pembelajaran berbasis web dengan memanfaatkan blog yang berdomain gratis merupakan inovasi yang dapat dilakukan dalam pembelajaran menulis di perguruan tinggi. Hal ini sesuai dengan pendapat Krisianto (2014) bahwa aktivitas utama dalam mengelola blog (bloging) adalah membuat artikel dan mempostingnya dalam blog.

Pembelajaran berbasis web akan memberikan kesempatan mahasiswa mengemukakan gagasannya dalam bahasa tulis, sehingga keterampilan menulis mahasiswa meningkat.Hal ini berartipembelajaran berbasis web dapat mendukung hasil belajar siswa. Seperti hasil penelitian yang dilakukan oleh Sunwinarti dan Suwito (2016) menunjukkan rata-rata hasil belajar yang dilakukan dengan menggunakan pembelajaran berbasis web lebih tinggi dibandingkan pembelajaran yang tidak berbasis web.

Menulis dianggap sulit karena kesulitan mengemukakan gagasan dalam bahasa tulis. Kesulitan dalam menuangkan gagasan yang dialami mahasiswa karena kurang latihan dalam menulis. Padahal sebagai calon guru Sekolah Dasar (SD) mahasiswa memerlukan kemampuan menulis yang baik, agar dapat menyediakan bahan bacaan yang baik. Tulisan kreatif yang dimaksud berkaitan dengan penulisan karya sastra yang difokuskan pada penulisan cerita anak. Nurgiantoro (2013) menyimpulkan bahwa cerita anak adalah cerita yang umumnya berisi tentang cerita kehidupan, tetapi penyajian cerita disesuaikan dengan tingkat perkembangan siswa.

Proses pembelajaran menulis berbasis web mengacu pada pendapat Tomkins \& Hoskisson (1995) yang terdiri dari lima tahap menulis, yaitu: a) prewriting, b) drafting, c) revising, d) editing, e) publishing. Tahap pertama, tahap pra penulisan (prewritting) dilakukan untuk mempersiapkan tulisan yang akan ditulis. Beberapa hal yang akan dilakukan pada tahap ini adalah memilih topik; mempertimbangkan fungsi tulisan; identifikasi pembaca; pertimbangan bentuk tulisan; dan mengorganisir ide. Kegiatan mengorganisir ide pada tahap ini dilakukan dengan mengidentifikasi unsur cerita yang telah disajikan; menceritakan kembali sebuah cerita; dan menceritakan sebuah gambar.

Tahap kedua, yaitu tahap penyusunan (drafting) merupakan tahap untuk menuangkan ide dalam bahasa tulis tanpa memperhatikan kesalahan teknis. Tulisan yang dihasilkan pada tahap ini disebut sebagai draf kasar karena memerlukan perbaikan pada tahap selanjutnya. Pada tahap ketiga, yaitu revisi (revising) adalah tahap untuk membaca kembali draf dan berbagi draf, kemudian memperbaiki draf berdasarkan umpan balik atau masukan yang telah didapatkan. Tahap keempat, yaitu edit (editing) adalah tahap untuk memperbaiki naskah secara total. Tahap kelima, yaitu 
menerbitkan tulisan (publishing) adalah tahap yang dilakukan agar orang lain dapat membaca tulisan yang sudah baik, sehingga dapat memberi nilai manfaat bagi orang lain.

Pembelajaran menulis kreatif berbasis we dilaksanakan pada salah satu pokok bahasan dalam matakuliah keterampilan bahasa dan sastra Indonesia, dilakukan dengan mengkombinasikan tahap menulis yang dikemukakan oleh Tomkins \& Hoskisson tersebut. Alur pelaksanaan pembelajaran tersebut secara jelas dapat tersaji dalam gambar 1.

\section{Prewriting (Pra-Penulisan)}

Pengumpulan ide pada tahap inidilakukan dengan mengidentifikasi unsur cerita; menceritakan kembali sebuah cerita; serta bercerita dari gambar. Kegiatan tersebut dilakukan melalui kegiatan membaca dan mengomentari postingan blog yang telah di sediakan.

\section{Drafting (Tahap Penyusunan)}

Berdasarkan ide yang telah terkumpul dari aktivitas membaca dan mengomentari postingan, mahasiswa menyusun draf kasar dan menuangkannya pada kolom komentar yang telah disediakan.

\section{Revising (Revisi)}

Pada tahap ini, mahasiswa membaca kembali draf kasar yang telah ditulisnya; berbagi tulisannya; dan saling membaca draf kasar anggota kelompoknya. Mahasiswa memperbaiki tulisannya berdasarkan masukan (komentar) dari anggota kelompoknya dan meletakkan hasil revisiannya pada kolom komentar yang telah disediakan.

\section{Editing (Edit)}

Pada tahap ini, mahasiswa mengedit tulisannya secara total baik dari segi pilihan kata, kalimat, dan ketepatan EYDdan meletakkannya pada kolom komentar yang telah disediakan.

\section{2}

\section{Publishing}

Mahasiswa mempublikasikan tulisan yang telah diedit di blog masing-masing dan menuliskan alamat web yang memuat tulisan tersebut pada kolom komentar yang telah disediakan.

\section{Gambar 1. Proses Pembelajaran Menulis Kreatif Berbasis Web}

Pembelajaran menulis kreatif berbasis web seperti proses pada gambar 1 dilakukan dengan mengomentari postingan yang telah disediakan dan mengolah web dengan memposting tulisan yang telah melewati tahap edit.

Kemampuan menulis kreatif mahasiswa dalam bentuk cerita anak dapat diketahui sejauh mana peningkatannya setelah dilakukan penilaian. Arikunto (2009) mengemukakan bahwa, penilaian merupakan pengambilan keputusan yang didasarkanpertimbangan tertentu. Penilaian dalam menulis kreatif dilakukan dengan memperhatikan komponennya. Komponen penilaian menulis kreatif cerita anak mencakup unsur-unsur intrinsik dalam cerita yang meliputi tokoh, penokohan, alur, setting, dan tema. Hal ini seperti yang dikemukakan oleh Nurgiantoro (2013) bahwa penilaian tulisan sastra anak meliputi tujuh hal, yaitu: a) alur cerita, b) penokohan, c) tema dan moral, d) latar, e) stile, f) ilustrasi, dan g) format. Penilaian dilakukan dengan mengacu pada rublik penilaian cerita anak yang terdapat pada tabel 1 sebagai berikut. 
Tabel 1. Rublik Penilaian Cerita Anak

\begin{tabular}{|c|c|c|}
\hline \multirow{2}{*}{\multicolumn{2}{|c|}{$\begin{array}{lc}\text { No. } & \text { Aspek } \\
\text { 1. } & \text { Alur Cerita }\end{array}$}} & Indikator \\
\hline & & $\begin{array}{l}\text { a. Berkaitan dengan dunia anak } \\
\text { b. Kesederhanaan alur dan sesuai dengan kaidah pengembangan }\end{array}$ \\
\hline 2. & Penokohan & $\begin{array}{l}\text { a. Klasifikasi tokoh cerita jelas } \\
\text { b. Karakter tokoh diuraikan secara langsung }\end{array}$ \\
\hline 3. & $\begin{array}{l}\text { Tema dan } \\
\text { Moral }\end{array}$ & $\begin{array}{l}\text { a. Tema mengusung kebenaran dan mengajarkan kebaikan } \\
\text { b. Ajaran moral disampaikan secara konkret lewat sikap tokoh cerita }\end{array}$ \\
\hline & Latar & $\begin{array}{l}\text { a. Penggambaran latar dilakukan secara konkret } \\
\text { b. Latar disampaikan dengan jelas, tidak berbelit-belit }\end{array}$ \\
\hline & Stile & $\begin{array}{l}\text { a. Bahasa yang digunakan sederhana } \\
\text { b. Cerita mudah dipahami dan memiliki daya tarik }\end{array}$ \\
\hline
\end{tabular}

Berdasarkan tabel 1 dapat diketahui terdapat dua aspek yang tidak masuk dalam rublik penilaian, yaitu ilustrasi dan format karena penilaian akan difokuskan pada kemampuan menulis mahasiswa. Tujuan penelitian ini yaitu menghasilkan perangkat pembelajaran berupa silabus, SAP, media pembelajaran berbasis web, dan instrumen penilaian menulis kreatif yang layak dan efektif dalam meningkatkan kemampuan menulis kreatif mahasiswa.

\section{METODE}

Penelitian ini adalah penelitian Research and Development (R\&D), dikembangkan Borg and Gall (1983: 775) yang tahapannya terdiri dari: 1) penelitian dan pengumpulan informasi; 2) perencanaan; 3) pengembangan draf produk; 4) uji coba awal dan perbaikan produk; 5) uji coba lapangan dan perbaikan produk; 6) uji coba lapangan operasional dan penyempurnaan produk akhir; serta 7) desiminasi. Mengingat keterbatasan waktu penelitian, tahap pengembangan dilakukan sampai tahap penyempurnaan produk akhir.

Subjek uji coba awal dalam penelitian adalah empat mahasiswa PGSD semester IV tahun ajaran 2017/2018. Subjek uji coba lapangan terdiri dari sepuluh mahasiswa PGSD semester IV tahun ajaran 2017/2018. Subjek uji coba lapangan operasional terdiri dari 38 mahasiswa PGSD semester II tahun ajaran 2017/2018 yang menempuh matakuliah keterampilan bahasa dan sastra Indonesia

Subjek uji coba lapangan operasional, terbagi menjadi dua kelompok. Kelas A berjumlah 18 mahasiswa dan kelas B terdiri dari 20 mahasiswa. Kedua kelompok tersebut diambil sampelnya menggunakan teknik cluster random sampling.Kelas yang dijadikan sampel atau diberi perlakuan yaitu kelas A, sedangkan kelas Bdijadikan kelas kontrol. Instrumen penelitian menggunakan angket mahasiswa dan tes kemampuan menulis.Teknik analisis data yang digunakan pada tahap uji coba awal dan lapangan adalah deskriptif. Sedangkan pada tahap uji coba lapangan operasional, terdapat tambahan uji hipotesis.

\section{HASIL DAN PEMBAHASAN}

Hasil

Pengembangan pembelajaran berbasis webtelah melewati beberapa tahapan pengembangan sebagai berikut.

Tahap Pengumpulan Informasi

Pada tahap ini diperoleh informasi bahwa kemampuan menulis kreatif mahasiswa masih rendah. Hal ini dilihat dari rata-rata menulis kreatif mahasiswa 
sebesar 63,32. Permasalahan yang dihadapi mahasiswa pada saat menulis, yaitu: 1) minimnya ide; 2) kesulitan menuangkan ide dalam bahasa tulis; serta 3) minimnya pembelajaran menulis kreatif yang telah dilakukan. Berdasarkan permasalahan tersebut, dikembangkan pembelajaran berbasis web berupa perangkat pembelajaran yang terdiri dari silabus, SAP, instrumen penilaian menulis kreatif, dan media pembelajaran berbasis web.

\section{Tahap Perancangan}

Terdapat beberapa langkah yang dilakukan dalam tahap perancangan, langkah pertama yaitu penyusunan peta kebutuhan pengembangan pembelajaran berbasis web. Langkah kedua yaitu perumusan tujuan perkuliahan, indikator capaian, dan pokok bahasan dalam silabus. Langkah ketiga yaitu perencanaan skenario pembelajaran dalam SAP.Langkahkeempat yaitu penyusunan media berbasis webyang dibuat dengan memanfaatkan domain gratis yaitu wordpress. Langkah kelima yaitu penyusunan instrumen penilaian menulis kreatif yang dibuat dalam google formulir.

\section{Tahap Pengembangan Draf Produk}

Tahap pengembangan draf produk dilakukan untuk menghasilkan produk yang standar setelah dilakukan validasi oleh ahli materi. Ahli materi menilai baik produk yang dikembangkan skor total sebesar 82 dari semua aspek. Saran dari ahli materi terkait produk yang dikembangkan yaitu pada bagian instrumen penilaian menulis kreatif perlu ditambah kriteria penilaianna, sehingga penilai dapat menilai dengan patokan yang jelas.

\section{Uji Coba Awal dan Perbaikan Produk}

Uji coba awal dilaksanakan terbatas pada empat mahasiswa semester IV. Keempat mahasiswa tersebut mengikuti proses pembelajaran menulis kreatif berbasis web, kemudian diminta untuk mengisi angket terbuka berupa masukan terkait pembelajaran tersebut. Berdasarkan uji coba yang telah dilakukan tersebut, diperoleh beberapa masukan, yaitu: 1) prosedur pembelajaran perlu disederhanakan; 2) bagian pra-penulisan perlu disesuaikan isinya dengan alokasi waktu yang disediakan. Perbaikan produk meliputi skenario pembelajaran yang tertuang dalam SAP dan materi dalam tahap prapenulisan dalam media pembelajaran berbasis web.

\section{Uji Coba Lapangan dan Perbaikan Produk}

Uji coba lapangan dilaksanakan dengan subjek sebanyak sepuluh mahasiswa semester IV. Pada saat uji coba lapangan, mahasiswa juga mengikuti proses pembelajaran menulis kreatif berbasis web. Masukan yang diperoleh pada tahap ini, yaitu perlu ada perbaikan dalam aplikasi penilaian didalam media berbasis web tersebut agar mudah diakses. Perbaikan produk mencakup media pembelajaran berbasis web pada bagian publikasi yang menghubungkan dengan google formulir.

\section{Uji Coba Lapangan Operasional dan Penyempurnaan Produk Akhir}

Uji coba lapangan dilaksanakan dengan subjek sebanyak 38 mahasiswa semester II yang sedang menempuh mata kuliah Keterampilan Bahasa dan Sastra Indonesia. Subjek tersebut terbagi menjadi dua kelompok, kelompok A dengan jumlah mahasiswa 18 orang, dijadikan kelas eksperimen. Sementara itu, kelompok B dengan jumlah mahasiswa sebanyak 20 orang dijadikan kelas kontrol. Sebelum dilakukan uji coba lapangan operasional, subjek diberikan pretest untuk mengetahui kemampuan awal menulis kreatif mahasiswa. Hasil pretest diketahui rata-rata nilai menulis kreatif kelas kontrol adalah 62,8, sedangkan rata-rata di kelas eksperimen sebesar 63,89.

Perlakuan berupa pembelajaran berbasis web dilaksanakan di kelas eksperimen setelah dilakukan pretest. Kedua kelas selanjutnya diberi postest dan 
didapatkan rata-rata di kelas kontrol sebesar 69,7 sedangkan di kelas eksperimen sebesar 76,2. Uji hipotesis dilakukan terhadap data: 1) pretest dan postest kelompok eksperimenserta 2) postest kelompok kontrol dan eksperimen setelah semua data dinyatakan berdistribusi normal dan homogen. Dari hasil uji hipotesis diperoleh taraf signifikansi (2-tailed) masing-masing sebesar 0,00 dan 0,04 yang lebih kecil dari 0,05 (taraf signifikansi yang digunakan). Maka, disimpulkan bahwa terdapat perbedaan ratarata antara data hasil pretest dan postest kelompok eksperimen.Penyempurnaan produk akhir dilakukan terhadap keseluruhan produk yang dikembangkan, meliputi: 1) silabus, 2) SAP, 3) penilaian menulis kreatif, dan 4) media pembelajaran berbasis web.

\section{Pembahasan}

\section{Kelayakan Pembelajaran Berbasis Web}

Kelayakan pembelajaran berbasis web dilihat dari penilaian yang dilakukan ahli materi, dengan total skor sebesar 82. Skor ini interpretasi dengan katagori baik, sesuai dengan standar nilai yang dikemukakan Arikunto (2009) yang terdiri dari enam standar yaitu baik sekali (9); baik (8); lebih dari cukup (7); cukup (6); kurang (5); dan kurang sekali (4). Maka, dapat disimpulkan bahwa pembelajaran berbasis web yang dikembangkan dikatakan telah memenuhi standar kelayakan dengan nilai baik.

Kelayakan pembelajaran berbasis web juga dinilai dari respon mahasiswa yang dijadikan sebagai subjek uji coba awal, uji coba lapangan, dan uji coba lapangan operasional (kelompok eksperimen). Penilaian kelayakan dari respon mahasiswa dapat dilihat dari gambar 2 sebagai berikut.

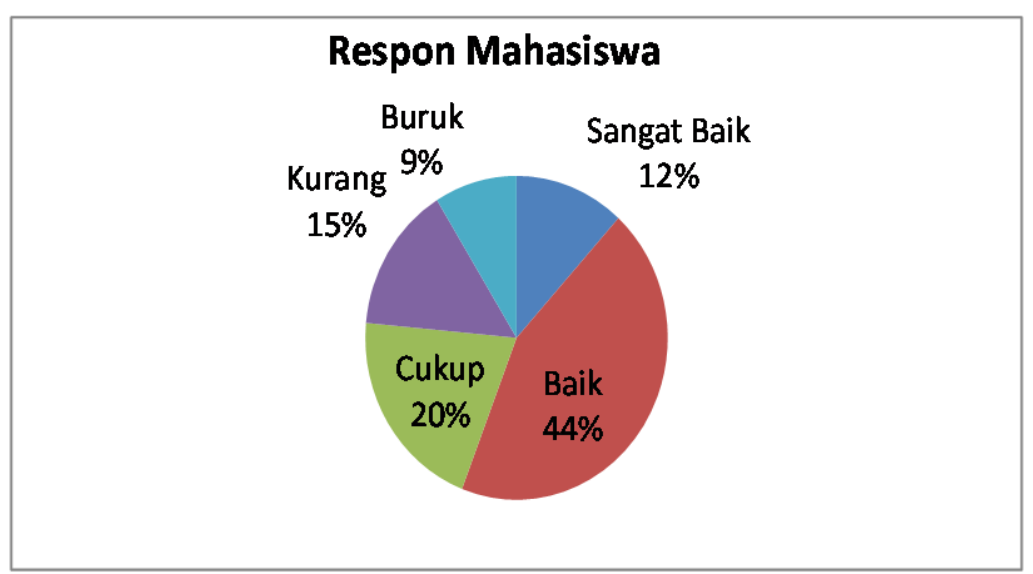

Gambar2. Respon Mahasiswa Terkait Pembelajaran Berbasis Web

Berdasarkan gambar 2 dapat diketahui bahwa pembelajaran berbasis web dinilai baik oleh sebagian besar mahasiswa, yaitu sebanyak 4 mahasiswa atau $12 \%$ menilai sangat baik, 15 mahasiswa atau 44\% menilai baik, 7 mahasiswa atau 20\% menilai cukup, 5 mahasiswa atau 15\% menilai kurang, dan 3 mahasiswa atau 9\% menilai buruk.Penilaian yang baik oleh sebagian besar subjek menunjukkan bahwa pembelajaran berbasis web dapat dikatakan layak, digunakan dalam proses pembelajaran, khususnya dalam pembelajaran menulis kreatif.

\section{Keefektifan Pembelajaran Berbasis Web}

Keefektifan pembelajaran berbasis web dalam meningkatkan kemampuan menulis kretif mahasiswa dilihat dari hasil uji coba lapangan operasional. Hasil tersebut menunjukkan perbedaan rata-rata yang signifikan antara rata-rata pretest-postest menulis kreatif di kelas eksperimen serta postest menulis kreatif di kelas kontrol dan eksperimen. Seperti yang telah diuraikan di hasil penelitian bahwa perbedaan rata-rata yang signifikan tersebut, diikuti oleh peningkatan rata-rata kemempuan menulis kreatif mahasiswa setelah 
diberi perlakuan, yaitu pembelajaran berbasis web.

Pembelajaran menulisakan membuat mahasiswa turut berproses memaksimalkan seluruh kemampuan otaknya, sehingga dapat menuangkan gagasan dalam bahasa tulis. Hal ini sesuai dengan konsep menulis yang dikemukakan oleh Deporter \& Hernacki (2009) bahwa menulis sebagai proses yang melibatkan seluruh belahan otak manusia. Setiap belahan otak bekerja sama dalam mengumpulkan informasi, kemudian diterjemahan oleh belahan otak yang lain untuk menuangkan ide dalam bahasa tulis.

Menulis sebagai proses dapat muncul dengan adanya sebuah pembelajaran menulis yang dilakukan. Hal ini sesuai dengan hasil penelitian Zulaeha (2013) bahwa kemampuan menulis meningkat setelah dilakukan pembelajaran menulis. Kemampuan menulis kreatif mahasiswa juga meningkat, setelah diterapkannya pembelajaran berbasis web.Pembelajaran menulis kreatif berbasis web mempunyai keunggulan. Keunggulan tersebut seperti yang dikemukakan oleh Marisa (2014) bahwa pembelajaran berbasis web akan menjadikan kualitas belajar mahasiswa lebih baik yang diikuti semangat dan motivasi mengikuti pembelajaran. Dengan demikian, kualitas belajar yang baik tersebut akan selalu terjaga karena adanya semangat dan motivasi yang muncul dari dalam diri untuk belajar.

\section{SIMPULAN}

Hasil pengembangan pembelajaran berbasis web berupa silabus, SAP, media pembelajaran berbasis web, dan instrumen penilaian menulis kreatifdinyatakan layak digunakan dalam proses pembelajaran. Mahasiswa juga memberikan respon yang positif terhadap pembelajaran berbasis web. Selain itu, pembelajaran berbasis web juga efektif dalam meningkatkan kemampuan menulis kreatif mahasiswa. Hal ini dapat dilihat dari perbedaan rata-rata yang signifikan antara dua kelompok sebelum dan sesuadah diberikan perlakuan.

Produk yang dikembangkan memiliki keunggulan, yaitu dapat dimanfaatkan oleh semua kalangan secara gratis, karena menggunakan domaian gratis. Dosen dan mahasiswa memperoleh pengalaman mengajar dan belajar dengan menerapkan teknologi informasi dengan lebih baik. Selain itu, pembelajaran berbasis web juga dapat menyiapkan mahasiswa untuk memanfaatkan kemajuan teknologi dengan dalam kehidupannya sehari-hari.

Saran-saran yang dapat diberikan yaitu, sebelum pelaksanaan pembelajaran sebaiknya jaringan internet dicek terlebih dahulu. Hal ini dilakukan agar pembelajaran berbasis web dapat dilaksanakan tanpa ada hambatan koneksi. Dengan demikian, mahasiswa dapat fokus dalam mengembangkan kemampuan menulisnya. Pembelajaran berbasis web di Universitas Muhadi Setiabudi dapat dijadikan alternatif pembelajaran yang inovatif dan kreatif. Pembelajaran berbasis webjuga dapat diterapkan pada materi lain, sehingga dapat menambah wawasan dan pengalaman mahasiswa dalam proses pembelajaran. Penerapan pembelajaran tersebut pada materi lain, perlu disesuaikan terkait skenario pembelajaran, isi materi, dan instrumen penilaian yang digunakan.

\section{DAFTAR PUSTAKA}

Arikunto, S. (2009). Dasar-dasar evaluasi pendidikan. Jakarta: Bumi Aksara

Borg, W.R., Gall, M.D., \& Gall. J.P. (2003). Educational research: an introduction. New York: Pearson Education. Inc.

Dalman. (2016). Keterampilan menulis. Jakarta: Rajawali Pers 
Deporter, B \& Hernacki, H. (2009). Quantum learning membiasakan belajar nyaman dan menyenangkan (Terjemahan Alwiyah Abdurrahman). New York: Dell Publising (Buku asli diterbitkan tahun 1992)

Krisianto, A. (2014). Buku pintar internetan connect for beginner. Bandung: Oasebuku

Marisa, dkk. (2014). Komputer dan media pembelajaran. Jakarta: Universitas Terbuka

Nurgiantoro, B. (2010). Sastra anak pengantar pemahaman dunia anak. Yogyakarta: Gadjah Mada University Press.

Sunwinarti \& Suwito, D. (2016). Pengembangan media pembelajaran berbasis web untuk meningkatkan hasil belajar dasar-dasar mesin kelas $X$ di SMK negeri 3 Buduran Sidoarjo. JurnalPendidikanTeknikMesin, 4 (3), 21-27

Tompkins, G \&Hoskisson, K.(1995).Language art content and teaching strategies. United States of America: Prentice-Hall

Zulaeha. (2013). Model Inkuiri Terpimpin Berpasangan dalam Pembelajaran Menulis Kreatif Konservasi Budaya Berbasis Pembentukan Karakter Peserta Didik. Jurnal Penelitian Pendidikan, 30 (1), 117-124 